\title{
Biosorption of lead by Gram-ve capsulated and non-capsulated bacteria
}

\author{
Saleh M Al-Garni \\ Biological Sciences Department, Faculty of Science, King Abdulaziz University, PO Box 80203, Jeddah 21589, Saudi Arabia
}

\begin{abstract}
The biosorption of lead by two Gram-ve bacteria, either non-capsulated (Citrobacter freundii) or capsulated (Klebsiella pneumoniae) was characterised. Lead biosorption was found to be influenced by the $\mathrm{pH}$ of the solution, initial metal concentration, and amount of the dried powdered cells and contact time. Thus, the optimum biosorption capacity, by the two tested bacteria, was attained at $\mathrm{pH} 4$, initial lead concentration of about $481.2 \mathrm{mg} / \ell$ and contacted with $2 \mathrm{~g}$ dried cells $/ \ell$ for 100 $\mathrm{min}$. However, the dried powdered cells of both organisms can be safely stored for long periods $(125 \mathrm{~d})$ at room temperature $\left(25 \pm 2^{\circ} \mathrm{C}\right)$ without any loss of their biosorption efficiency, i.e. their binding sites not affected by storage. The results revealed that the presence of capsule (K. pneumoniae) increased the biosorption efficiency of the bacterium.
\end{abstract}

Keywords: biosorption, Gram-ve bacteria, capsulated bacteria, Citrobacter freundii, Klebsiella pneumoniae

\section{Introduction}

Mobilisation of heavy metals in the environment due to industrial activities is of serious concern due to the toxicity of these metals in humans and other forms of life. Removal of toxic heavy metals from industrial waste waters is essential from the standpoint of environmental pollution control (Puranik and Pakniker, 1999; Guangyu and Thiruvenkatachari, 2003). Among the toxic heavy metals, mercury, lead and cadmium, "called the big three" are in the limelight due to their major impact on the environment (Volesky, 1994). Many industries, especially plating and those manufacturing batteries, pigments and ammunition, release heavy metals such as lead, cadmium and zinc in wastewaters. Lead and cadmium are potent neurotoxic metals (Puranik and Pakniker, 1997).

Chemical oxidation, reduction, precipitation, adsorption, solidification, electrolytic recovery, and ion exchange are some of the physicochemical wastewater treatment processes which are being used for metal removal. Application of such methods, however, is sometimes restricted because of technical or economical constraints. (Bossrez et al.,1997; Yu and Kaewsarn, 1999). Biological metal removal (biosorption) has distinct advantages over conventional methods: it is non-polluting and it can be highly selective, more efficient, easy to operate, and hence cost-effective for treatment of large volumes of wastewaters containing low metal concentrations (Puranik and Pakniker, 1999).

Various biomass materials including microbial biomass have been identified and documented as effective metal-removing agents (Veglio and Beolchini, 1997; Volesky and Holan, 1995). The present work aimed to characterise lead biosorption by local Gram-ve bacteria, either non-capsulated (Citrobacter freundii) or capsulated (Klebsiella pneumonia).

\footnotetext{
* To whom all correspondence should be addressed.

兽 +96626952291; fax: +96626952290;

e-mail: saleh895_4@hotmail.com

Received 21 January 2005; accepted in revised form 29 April 2005.
}

\section{Materials and methods}

\section{Micro-organisms}

Citrobacter freundii and Klebsiella pneumoniae were kindly provided by Microbiology Lab, King Abdulaziz Medical City, Jeddah, Saudi Arabia, and their identification was routinely assessed using Sin: Desca 5744 Vite apparatus and API 20E indicator for Gram-ve bacteria.

\section{Growth and preparation of the powdered dried dead cells}

The tested bacteria were maintained on nutrient agar slants. The stock cultures were transferred weekly and stored at $10^{\circ} \mathrm{C}$ in a refrigerator.

Biomass of the tested bacteria was developed by growing in MacConky broth medium (Nentech, LTD, UK), pH 7.0 at $37 \pm 1^{\circ} \mathrm{C}$ for $48 \mathrm{~h}$, under shaken conditions $(120 \mathrm{r} / \mathrm{min})$. Cells were harvested by centrifugation at $8000 \mathrm{r} / \mathrm{min}$ for $10 \mathrm{~min}(\mathrm{~J}-2 / \mathrm{C}$ plus centrifuge). Harvested cells (biomass) were washed twice with deionised distilled water and dried in an oven at $80^{\circ} \mathrm{C}$ for $48 \mathrm{~h}$. To assess complete death of the dried cells, samples of the dried cells were inoculated to Petri-dishes containing MacConky agar medium, absence of any growth indicating positive results (complete death of the bacteria). The dried cells were then ground in a porcelain mortar to obtain a fine powder $(0.2 \mathrm{~mm})$, and stored at $5^{\circ} \mathrm{C}$, until use.

\section{Metal solution}

A stock solution of lead (1 $200 \mathrm{mg} / \ell)$ was prepared by dissolving $0.0113 \mathrm{M}$ of lead nitrate in deionised distilled water, shaking it for $15 \mathrm{~min}$ and then leaving it to stand for $24 \mathrm{~h}$ to obtain complete dissolution. Stock solution was diluted with deionised distilled water to obtain the necessary concentrations. Solutions were adjusted to desired $\mathrm{pH}$ values with $0.1 \mathrm{M}$ sodium hydroxide and $0.1 \mathrm{M}$ nitric acid. The initial lead concentration was measured at the beginning of all experiments carried out using an atomic 
absorption spectrophotometer (AAS) (Unicam 929 AA Spectrometer, UK) and not as calculated from the dilution.

\section{Metal absorption studies}

A batch equilibrium method was used to determine sorption of lead by $C$. freundii and $K$. pneumoniae. A set of $250 \mathrm{~m} \ell$ Erlenmeyer flasks containing $50 \mathrm{~m} \ell$ of the tested lead solution was used in the experiments. Powdered dried dead cells $(100 \mathrm{mg}$, unless otherwise stated) were exposed to metal solution for $60 \mathrm{~min}$ (unless otherwise stated) at $25 \pm 2^{\circ} \mathrm{C}$ on a rotary shaker at $150 \mathrm{r} / \mathrm{min}$. The dried powdered cells were separated by centrifugation at $10000 \mathrm{r} / \mathrm{min}$ for $10 \mathrm{~min}$, and supernatants were analysed for residual lead concentration on an atomic absorption spectrophotometer. Metal adsorbed by the tested dried cells (mg metal/g dry cells) was calculated (Volesky and May-Phillips, 1995) as:

$$
\mathrm{Q}=\mathrm{V}(\mathrm{Ci}-\mathrm{Cf}) / 1000 \mathrm{M}
$$

where:

$$
\begin{aligned}
\mathrm{Q}= & \text { specific lead uptake }(\mathrm{mg} \\
& \text { lead/g biosorbent) } \\
\mathrm{V}= & \text { volume of lead solution }(\mathrm{m} \ell) \\
\mathrm{Ci}= & \text { initial concentration of lead in the solution } \\
& (\mathrm{mg} / \ell) \\
\mathrm{Cf}= & \text { final concentration of lead in the solution }(\mathrm{mg} / \ell) \\
\mathrm{M}= & \text { mass of the powdered dried cells }(\mathrm{g})
\end{aligned}
$$

The lead sorption ability of the dried cells was determined by the above procedure, in all of the following experiments, unless otherwise stated.

\section{Effect of $\mathrm{pH}$}

To test the effect of $\mathrm{pH}$ on biosorption, the dried powdered cells of $C$. freundii and $K$. pneumoniae were suspended in lead solutions with different $\mathrm{pH}$ values, ranging from 2 to 7 , for $60 \mathrm{~min}$ on a rotary shaker at $150 \mathrm{r} / \mathrm{min}$. Thereby, the necessary analysis was carried out.

\section{Effect of initial lead concentration}

Metal solutions $(50 \mathrm{~m} \ell)$ of varying concentrations of lead (ranging from 98.2 to $579.3 \mathrm{mg} / \ell$, as measured at the beginning of the experiment by AAS ) adjusted to the optimum $\mathrm{pH}$ of 4 , were treated with $100 \mathrm{mg}$ of the dried powdered cells of $C$. freundii and $K$. pneumoniae. Thereby, the biosorption was completed and necessary analyses were carried out.

\section{Effect of dried powdered cells concentration}

Dried powdered cells ( 50 to $500 \mathrm{mg}$ ) were exposed to $50 \mathrm{~m} \ell$ of lead solution $(481.2 \mathrm{mg} / \ell \approx 24.1 \mathrm{mg} / 50 \ell)$ at the optimum $\mathrm{pH} 4$ for $60 \mathrm{~min}$ on a rotary shaker at $150 \mathrm{r} / \mathrm{min}$. Thereby, the residual lead in the supernatant after centrifugation at $10000 \mathrm{r} / \mathrm{min}$ for 10 min was measured using AAS.
TABLE 1

values on biosorption of lead by the dried owdered cells of $C$. freundii and $K$. pneumoniae

value conc. * $^{*} \quad \begin{aligned} & \text { lead conc. } \\ & \text { leorbed }\end{aligned}$

$\begin{array}{lll}(\mathrm{mg} / \ell) & (\mathrm{mg} / \ell) \quad \text { lead }^{* *}\end{array}$

(\%)

cific lead

uptake u** $^{* *}$

(mg/g dry

wt.)

\begin{tabular}{l|r} 
& wt.) \\
\hline 7.2 & 5.7
\end{tabular}

\begin{tabular}{r|r|r|r|r|}
\hline 3 & $153.2 \pm 2.8$ & $119.4 \pm 3.2$ & 22.1 & 16.9 \\
\hline 4 & $147.2 \pm 2.6$ & $94.5 \pm 2.5$ & 35.8 & 26.4 \\
\hline 5 & $136.1 \pm 3.5$ & $102.5 \pm 3.4$ & 24.7 & 16.8 \\
\hline 6 & $125.7 \pm 4.8$ & $103.4 \pm 3.5$ & 17.8 & 11.2 \\
\hline 7 & $120.6 \pm 1.1$ & $100.4 \pm 5.7$ & 16.8 & 10.1 \\
\hline 2 & $158.8 \pm 5.0$ & $146.1 \pm 3.1$ & 8.1 & 6.4 \\
\hline 3 & $153.2 \pm 2.8$ & $102.1 \pm 3.6$ & 33.4 & 25.6 \\
\hline 4 & $147.2 \pm 2.6$ & $83.5 \pm 2.2$ & 43.3 & 31.9 \\
\hline 5 & $136.1 \pm 3.5$ & $101.8 \pm 3.4$ & 25.2 & 17.2 \\
\hline 6 & $125.7 \pm 4.8$ & $112.5 \pm 3.9$ & 10.5 & 6.6 \\
\hline 7 & $120.6 \pm 1.1$ & $108.4 \pm 5.6$ & 10.1 & 6.2 \\
\hline
\end{tabular}

$120.6 \pm 1.1$

6.2

spectrophotometry.

Biosorbed lead $(\%)=$

***Specific lead uptake $(\mathrm{mg} / \mathrm{g}$ dried cells $)=\frac{\text { Biosorbed lead }(\mathrm{mg} / \ell) \times \mathrm{D}}{1000 \times 0.1}$

\section{Effect of contact time}

To examine the lead biosorption mechanism, $100 \mathrm{mg}$ of dried powdered cells of the bacteria were contacted with $50 \mathrm{~m} \ell$ aliquots of lead solutions $(481.2 \mathrm{mg} / \ell)$ in $250 \mathrm{~m} \ell$ Erlenmeyer flasks. Flasks were incubated at $25 \pm 2^{\circ} \mathrm{C}$ for different time intervals (10 to $130 \mathrm{~min}$ ) and analysed for residual lead content.

\section{Effect of storage of the dried powdered cells}

To test the effect of storage on the efficiency of biosorbent material (its binding sites) to biosorb lead, the dried powdered cells of $C$. freundii and $K$. pneumoniae were stored at room temperature $\left(25 \pm 2^{\circ} \mathrm{C}\right)$ for $125 \mathrm{~d}$. Thereafter, $100 \mathrm{mg}$ of dried powdered cells (after different storage periods) were contacted with $50 \mathrm{ml}$ aliquots of lead solutions $(481.2 \mathrm{mg} / \ell)$ at the optimum $\mathrm{pH} 4$ for $100 \mathrm{~min}$. At the end of biosorption the residual lead content was measured.

Each treatment and assay were carried out in duplicate and the obtained results are the arithmetic mean.

\section{Results and discussion}

\section{Effect of $\mathrm{pH}$ values}

The results (Table 1) revealed that a $\mathrm{pH}$ range of 3 to 5, (especially $\mathrm{pH} 4$ ) was optimum for biosorption of lead by both bacteria. K. pneumoniae was more efficient in the biosorption process than C. freundii. At $\mathrm{pH} 4$ K. pneumonia sorbed about $20.7 \%$ and $20.8 \%$ more lead, as percentage and $\mathrm{mg} / \mathrm{g}$ dry cells (specific lead uptake), respectively, than $C$. freundii. Previous authors have reported that the prevailing $\mathrm{pH}$ value is one of the main factors in biosorption efficiency by different organisms (Leung et al., 2000; Lopez et al., 2000; Senthilkumaar et al., 2000; Jalali 
et al., 2002; Pagnanelli et al., 2003; Pardo et al., 2003). The $\mathrm{pH}$ affects the network of negative charges on the surface of the biosorbing cells and the chemistry of the walls, as well as physicochemistry and hydrolysis of the metal (Collins and Stotzky, 1996;Lopez et al., 2000). In accordance with our results, it has also been reported that $\mathrm{pH} 4.5$ was optimum for biosorption of lead by Citrobacter strain MCM B-181 and $\mathrm{pH}<3$ or $>5$ resulted in lower biosorption efficiency of lead (Puranik and $\mathrm{Pa}$ kniker, 1999; Guangyu and Thiruvenkatachari, 2003).

It was also reported that at highly acidic $\mathrm{pH}(<3)$ lead ions compete with $\mathrm{H}$ on the binding sites of microbial cell. However, at higher $\mathrm{pH}(>5)$ solubility of lead was lowered (Change et al., 1997; Gadd, 1988). These findings were in accordance with our results.

The higher efficiency of K.pneumoniae to absorb lead than $C$. freundii at the different tested $\mathrm{pHs}$ may be attributed to the presence of capsules. In accordance, it has previously been reported that $K$. pneumoniae accumulate cadmium on the cell-wall surface and through the capsule (Scott and Palmer, 1990).

\section{Effect of initial lead concentration}

The results shown in Table 2 revealed that specific metal uptake increased with increasing initial lead concentration with both bacteria and $K$. pneumoniae was again more efficient in biosorption at the different lead concentrations due to the presence of the capsule. The enhancement in metal sorption could be due to an increase in electrostatic interactions, involving sites of progressively lower affinity for metal ions (Al-Asheh and Duvnjak, 1995; Puranik and Pakniker, 1999). These data indicated that lead uptake by the two tested Gramve bacteria was chemically equilibrated and saturation was attained at an initial lead concentrations of 481.2 $\mathrm{mg} / \ell$. Thus, there was no increase in metal uptake for as long as the binding sites were saturated by the metal. At an initial lead concentration of about $481 \mathrm{mg} / \ell \mathrm{K}$. pneumoniae showed a $14.4 \%$ increase in biosorption over that attained by $C$. freundii $(42.8 \%)$. However, the percentage of biosorbed lead was regularly decreased with increasing initial lead concentration, as had been expected.

\section{Effect of dried powdered dead cells concentration}

The results given in Table 3 show that the specific metal uptake values obtained at various concentrations ( 1 to $10 \mathrm{~g} / \ell$ ) of dried powdered cells of $C$. freundii and $K$. pneumoniae were decreased with increasing dry mass concentrations. Thus, about $54.2 \%$ and $55.2 \%$ decreases were recorded for $C$. freundii and $K$. pneumoniae, respectively, as the dry mass increased from 1 to $10 \mathrm{~g} / \ell$. This could be attributed to interference between binding sites at higher concentrations (De Rome and Gadd, 1987). Reduction in zinc uptake by Rhizopus arrhizus with increasing biomass concentration was attributed to an insufficiency of metal ions in solution with respect to available binding sites by Fourest and Roux (1992). Similar observations were repeated by other workers (Al-Asheh and Duvnjak, 1995; Sampedro et al., 1995). Higher specific uptake at lower dry mass concentrations could be due to an increased metal-to-biosorbent ratio, which decreases upon an increase in dry mass concentration (Puranik
TABLE 2

Biosorption of different concentrations of lead by the dried powdered cells of $C$. freundii and $K$. pneumoniae at $\mathrm{pH} 4$

\begin{tabular}{|c|c|c|c|c|}
\hline Bacteria & $\begin{array}{c}\text { Initial lead } \\
\text { conc. } \\
(\mathrm{mg} / \ell)\end{array}$ & 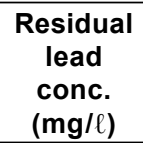 & $\begin{array}{l}\text { Bio- } \\
\text { sorbed } \\
\text { lead } \\
(\%)\end{array}$ & $\begin{array}{c}\text { Specific } \\
\text { Lead up- } \\
\text { take (mg/g } \\
\text { dry wt.) }\end{array}$ \\
\hline \multirow[t]{7}{*}{ C. freundii } & $98.2 \pm 1.9$ & $61.9 \pm 1.6$ & 36.9 & 18.1 \\
\hline & $147.2 \pm 2.6$ & $94.5 \pm 2.5$ & 35.8 & 26.4 \\
\hline & $196.4 \pm 2.3$ & $134.2 \pm 2.6$ & 31.7 & 31.1 \\
\hline & $285.4 \pm 5.7$ & $211.1 \pm 4.7$ & 26.1 & 37.2 \\
\hline & $392.3 \pm 8.2$ & $313.4 \pm 4.1$ & 20.1 & 39.5 \\
\hline & $481.2 \pm 4.6$ & $395.6 \pm 4.3$ & 17.8 & 42.8 \\
\hline & $579.3 \pm 7.3$ & $491.2 \pm 4.5$ & 15.2 & 44.1 \\
\hline \multirow[t]{7}{*}{ K. pneumoniae } & $98.2 \pm 1.9$ & $54.4 \pm 1.2$ & 44.6 & 21.9 \\
\hline & $147.2 \pm 2.6$ & $83.5 \pm 2.2$ & 43.3 & 31.9 \\
\hline & $196.4 \pm 2.3$ & $114.5 \pm 2.9$ & 41.7 & 41.0 \\
\hline & $285.4 \pm 5.7$ & $198.2 \pm 2.4$ & 30.6 & 43.6 \\
\hline & $392.3 \pm 8.2$ & $302.2 \pm 5.3$ & 23.0 & 45.0 \\
\hline & $481.2 \pm 4.6$ & $383.3 \pm 3.9$ & 20.3 & 48.9 \\
\hline & $579.3 \pm 7.3$ & $480.0 \pm 4.4$ & 17.2 & 49.7 \\
\hline
\end{tabular}

TABLE 3

Effect of mass of the dried powdered cells of $C$. freundii and $K$. pneumoniae on the biosorption of lead (481.2 $\mathrm{mg} / \ell)$ at $\mathrm{pH} 4$

\begin{tabular}{|c|c|c|c|c|}
\hline Bacteria & $\begin{array}{c}\text { Weight } \\
\text { of dried } \\
\text { cells } \\
(\mathrm{g} / \ell)\end{array}$ & $\begin{array}{c}\text { Residual } \\
\text { lead } \\
\text { conc. } \\
(\mathrm{mg} / \ell)\end{array}$ & $\begin{array}{c}\text { Bio- } \\
\text { sorbed } \\
\text { lead } \\
(\%) \\
\end{array}$ & $\begin{array}{c}\text { Specific } \\
\text { lead up- } \\
\text { take (mg/g } \\
\text { dry wt.) }\end{array}$ \\
\hline \multirow[t]{6}{*}{ C. freundii } & 1 & $431.2 \pm 2.8$ & 10.4 & 50.0 \\
\hline & 2 (basal) & $395.6 \pm 4.9$ & 17.8 & 42.8 \\
\hline & 4 & $332.9 \pm 3.2$ & 30.8 & 37.1 \\
\hline & 6 & $310.4 \pm 2.8$ & 35.5 & 28.5 \\
\hline & 8 & $272.5 \pm 2.3$ & 43.4 & 26.1 \\
\hline & 10 & $252.0 \pm 2.3$ & 47.6 & 22.9 \\
\hline \multirow[t]{6}{*}{ K. pneumoniae } & 1 & $427.2 \pm 2.9$ & 11.2 & 54.0 \\
\hline & 2(basal) & $383.3 \pm 3.9$ & 20.3 & 48.9 \\
\hline & 4 & $300.0 \pm 4.6$ & 37.7 & 45.3 \\
\hline & 6 & $260.9 \pm 2.5$ & 45.8 & 36.7 \\
\hline & 8 & $250.6 \pm 4.1$ & 47.9 & 28.8 \\
\hline & 10 & $241.0 \pm 2.2$ & 49.9 & 24.0 \\
\hline
\end{tabular}

and Pakniker, 1999). The percentage of biosorbed lead was increased regularly with increasing dry mass of the cells. Thus, as the mass increased from 1 to $10 \mathrm{~g} / \ell$ a 4.5 -fold increase in the percentage of sorbed lead was recorded with the two bacteria. This is in accordance with previous work in which it was reported that increased biomass concentration of the microbial cells was attained with metal sorption as $\mathrm{g} / \ell$ (Gupta and Keegan, 1998; Selatnia et al., 2004).

\section{Effect of contact time}

The data of lead uptake at the optimum $\mathrm{pH}$ (4) and initial lead concentration of $481.2 \mathrm{mg} / \ell$ contacted with $2 \mathrm{~g}$ dried cells (Table 4) showed that rapid uptake occurred in the first 10 min, accounting for about $4.5 \mathrm{mg}$ lead/min for $C$. freundii and about $6 \mathrm{mg}$ lead/min for $K$. pneumoniae. Time required for 


\begin{tabular}{|c|c|c|c|c|c|}
\hline \multicolumn{6}{|c|}{$\begin{array}{l}\text { TABLE } 4 \\
\text { Effect of different contact times of the dried powdered cells }(2 \mathrm{~g} / \ell) \text { of } C \text {. } \\
\text { freundii and } K \text {. pneumoniae on the biosorption of lead }(481.2 \mathrm{mg} / \ell \text { at } \mathrm{pH} 4\end{array}$} \\
\hline Bacteria & $\begin{array}{l}\text { Contact } \\
\text { time } \\
(\min )\end{array}$ & $\begin{array}{l}\text { Residual } \\
\text { lead conc. } \\
(\mathrm{mg} / \ell)\end{array}$ & $\begin{array}{l}\text { Bio- } \\
\text { sorbed } \\
\text { lead }(\%)\end{array}$ & $\begin{array}{l}\text { Specific } \\
\text { lead uptake } \\
\mathrm{mg} / \mathrm{g} \text { dry } \\
\text { cell }\end{array}$ & $\begin{array}{l}\text { Bio- } \\
\text { sorbed } \\
\text { lead } / \mathrm{min}\end{array}$ \\
\hline \multirow[t]{6}{*}{ C. freundii } & 10 & $436.0 \pm 3.4$ & 9.4 & 22.6 & 4.5 \\
\hline & 40 & $410.6 \pm 6.7$ & 14.7 & 35.3 & 1.8 \\
\hline & 60 (basal) & $395.6 \pm 4.9$ & 17.8 & 42.8 & 1.4 \\
\hline & 70 & $383.2 \pm 4.2$ & 20.4 & 49.0 & 1.4 \\
\hline & 100 & $364.1 \pm 4.2$ & 24.3 & 58.5 & 1.2 \\
\hline & 130 & $362.4 \pm 3.7$ & 24.7 & 59.4 & 0.9 \\
\hline \multirow[t]{6}{*}{ K. pneumoniae } & 10 & $421.2 \pm 3.8$ & 12.5 & 30.0 & 6.0 \\
\hline & 40 & $400.2 \pm 3.8$ & 16.8 & 40.5 & 2.0 \\
\hline & 60 (basal) & $383.3 \pm 3.9$ & 20.3 & 48.9 & 1.6 \\
\hline & 70 & $377.0 \pm 6.5$ & 21.7 & 52.1 & 1.5 \\
\hline & 100 & $358.0 \pm 5.7$ & 25.6 & 61.6 & 1.2 \\
\hline & 130 & $356.1 \pm 3.4$ & 26.0 & 62.5 & 1.0 \\
\hline
\end{tabular}

\begin{tabular}{|c|c|c|c|c|}
\hline \multicolumn{5}{|c|}{$\begin{array}{c}\text { TABLE } 5 \\
\text { Effect of storage of the dried powdered cells }(2 \mathrm{~g} / \ell) \text { of } \\
\text { C. freundii and } K . \text { pneumoniae on the biosorption of lead } \\
(481.2 \mathrm{mg} / \ell) \text { after } 100 \text { min of contact time at } \mathrm{pH} 4\end{array}$} \\
\hline Bacteria & $\begin{array}{c}\text { Storage } \\
\text { time } \\
\text { (days) }\end{array}$ & $\begin{array}{l}\text { Residual } \\
\text { lead conc. } \\
(\mathrm{mg} / \ell)\end{array}$ & $\begin{array}{l}\text { Bio- } \\
\text { sorbed } \\
\text { lead } \\
(\%)\end{array}$ & $\begin{array}{l}\text { Specific } \\
\text { lead uptake } \\
\text { (mg/g dry } \\
\text { cells) }\end{array}$ \\
\hline \multirow[t]{6}{*}{ C. freundii } & 2 (basal) & $364.1 \pm 4.2$ & 24.3 & 58.5 \\
\hline & 5 & $362.2 \pm 4.8$ & 24.7 & 59.5 \\
\hline & 25 & $362.1 \pm 3.9$ & 24.7 & 59.5 \\
\hline & 45 & $361.9 \pm 4.6$ & 24.8 & 59.6 \\
\hline & 85 & $363.7 \pm 6.0$ & 24.4 & 58.8 \\
\hline & 125 & $363.8 \pm 4.5$ & 24.4 & 58.7 \\
\hline \multirow[t]{6}{*}{ K. pneumoniae } & 2 (basal) & $358.0 \pm 5.7$ & 25.6 & 61.6 \\
\hline & 5 & $356.8 \pm 5.0$ & 25.8 & 62.2 \\
\hline & 25 & $359.6 \pm 5.8$ & 25.3 & 60.8 \\
\hline & 45 & $356.0 \pm 5.6$ & 26.0 & 62.6 \\
\hline & 85 & $356.1 \pm 4.1$ & 26.0 & 62.6 \\
\hline & 125 & $356.5 \pm 4.1$ & 25.9 & 62.4 \\
\hline
\end{tabular}

attaining equilibrium was less than $70 \mathrm{~min}$, under the tested conditions. It is known that the rate of metal uptake is influenced by factors affecting mass transfer from bulk solution to binding sites. It was indicated that various steps are involved in the transfer of metal from bulk solution to binding sites (Weber, 1985). First is the bulk transport of metal ions in solution phase, which is usually rapid because of mixing and advective flow (Gadd,1988). Second, film transport involves diffusion of metal through a hydrodynamic boundary layer around the biosorbent surface, and third, actual adsorption of metal ions by active sites of the biomass is considered to be rapid, equivalent to an equilibrium reaction (Weber, 1985).

In the case of lead biosorption by the tested bacteria, the experimental conditions allowed a normal mixing of solutes and biomass (dry cells) in the system that partially suppressed the kinetic limitations of the first and second steps and hence equilibrium was attained at less than $70 \mathrm{~min}$. Therefore, the kinetics of the process was influenced by the three steps. Similarly, it was reported that biosorption of lead by the fungus Phanerochaete chrysosporium was rapid in the first $15 \mathrm{~min}$ and equilibrium was attained after $3 \mathrm{~h}$ (Ceribasi and Yetis, 2001).

\section{Effect of storage of dried powdered cells}

The effect of storage of the biosorbent (dried powdered cells of the tested bacteria) for long periods ( $125 \mathrm{~d}$ ) at room temperature $25 \pm 2^{\circ} \mathrm{C}$ (Table5) indicated that the binding sites of the biomass still had the same capacity to biosorb lead ions. The specific metal uptakes by both C. freundii and K. pneumoniae dried powdered cells, were almost the same and no detectable differences before and after storage were recorded. This finding can be considered as an advantage of applying biosorbents over the other conventional methods, as the biosorbents can be safely stored for long periods without any loss of metal uptake efficiency. 


\section{Conclusion}

Different aspects of the biosorption of lead by the dried powdered dead cells of Gram-ve bacteria, one non-capsulated (Citrobacter freundii) and the other capsulated (Klebsiella pneumoniae) were characterised. Studies showed that lead biosorption capacity of the two organisms was influenced by the $\mathrm{pH}$ value of lead solution, initial lead concentration, amount of the sorbent and contact time. However, storage of the biosorbent cells for long periods had no detectable influence in their biosorption efficiency. The study showed that the capsule played an important role in biosorption efficiency, as $K$. pneumoniae showed higher efficiency to biosorb lead under the test conditions than the Gram-ve, non-capsulated $C$. freundii.

\section{References}

AL-ASHEH S and DUVNJAK Z (1995) Adsorption of copper and chromium by Aspergillus carbonarius. Biotechniol Prog. 11 638-642.

BOSSREZ S, REMACLE J and COYETTE J (1997) Adsorption of nickel on Enterococcus hirae cell walls. J. Chem. Tech. Biotechnol. 70 45-50.

CHANG JS, LAW R and CHANG C (1997) Biosorption of lead, copper and cadmium by biomass of Pseudomonas aeruginosa PU 21. Water Res. 31 1651-1658.

CERIBASI H and YETIS U (2001) Biosorption of Ni (II) and Pb (II) by Phanerochaete chrysosporium form binary metal system-kinetics. Water SA 27 (1) 15-20.

COLLINS YE and STOTZKY G (1996) Changes in the surface charge of bacteria caused by heavy metals do not affect survival. Can. J. Microbiol. 42 621-627.

DE ROME L and GADD GM (1987) Copper adsorption by Rhizopus arrhizus, Cladosporium resinae and Penicillium italicum. Appl. Microbiol. Biotechnol. 26 84-90.

FOUREST E and ROUX JC (1992) Heavy metal biosorption by fungal mycelial byproducts: mechanisms and influence of $\mathrm{pH}$. Appl. Microbiol. Biotechnol. 37 399-408.

GADD GM (1988) Accumulation of metals by microorganisms and algae. In: Rem HJ (ed.) Biotechnology. Weinheim, Germany. 401433.

GUANGYU Y and THIRUVENKATACHARI V (2003) Heavy metals removal from aqueous solution by fungus Mucor rouxii. Water Res. 37 (18) 4486-4496.

GUPTA G and KEEGAN B (1998) Bioaccumulation and biosorption of lead by poultry litter microorganisms. Poult Sci. Mar. 77 (3) 400 404.

JALALI R, GHAFOURIAN H, ASEF DAVARPANAH and SEPEHR S (2002) Removal and recovery of lead using non-living biomass of marine algae. J. Hazard. Matter 92 (3) 253-262.
LEUNG WC, WONG MF, CHUA H, LO W, Yu PH and LEUNG CK (2000) Removal and recovery of heavy metals by bacteria isolated from activated sludge treating industrial effluents and municipal wastewater. Water Sci. Technol. 41 233-240.

LOPEZ A, LAZARO N, PRIEGO JM and MARQUES AM (2000) Effect of $\mathrm{pH}$ on the biosorption of nickel and other heavy metals by Pseudomonas fluorescens 4F39. J. Indust. Microbiol. Biotechnol. 24 146-151.

PAGNANELLI F, ESPOSITO Fl, TORO L and VEGLIO F (2003) Metal speciation and $\mathrm{pH}$ effect on $\mathrm{Pb}, \mathrm{Cu}, \mathrm{Zn}$ an $\mathrm{Cd}$ biosorption onto Sphaerotilus natans: Langumuir-type empirical model. Water Res. 37 (3) 627-633.

PARDO R, HERGUEDAS M, BARRADO E and VEGA M (2003) Biosorption of cadmium, copper, lead and zinc by inactive biomass Pseudomonas putida. Anal. Bioanal. Chem. 37 (1) 26-32.

PURANIK PR and PAKNIKER KM (1997) Biosorption of lead and zinc from solutions using Streptoverticillium cinnamoneum waste biomass. J. Biotechnol. 55 113-124.

PURANIK PR and PAKNIKER KM (1999) Biosorption of lead, cadmium and zinc by Citrobacter strain MCM B-181: Characterization studies. Biotechnol. Progress 15 (2) 228-237.

SAMPEDRO MA, BLANCO A, LIAMA MJ and SERRA JL (1995) Sorption of heavy metals to Phormidium laminosum biomass. Biotechnol. Appl. Biochem. 22 355-366.

SCOTT J A and PALMER SJ (1990) Sites of cadmium uptake in bacteria used for biosorption. Appl. Microbiol. Biotechnol. 33 221-225.

SELATNIA A, BOUKAZOULA A, KECHID N, BAKHTI MZ, CHERGUI A and KERCHICH Y (2004) Biosorption of lead(II)from aqueous solution by a bacterial dead Streptomyces rimosus biomass. Biochem. Eng. J. 19 (2) 127-135.

SENTHILKUMAAR S, BHARATHI S, NITHYANANDHH D and SUBBURAM V (2000) Biosorption of toxic heavy metals from aqueous solution. Bioresour. Technol. 75 (2) 163-165.

VEGLIO F and BEOLCHINI F (1997) Removal of metals by biosorption: A review. Hydrometall. 44 301-316.

VOLESKY B (1994) Advances in biosorption of metals: selection of biomass types. FEMS. Microbiol. Rev. 14 291-302.

VOLESKY B and HOLAN Z (1995) Biosorption of heavy metals. Biotechnol. Prog. 11 235-250.

VOLESKY B and MAY-PHILLIPS HA (1995) Biosorption of heavy metals by Saccharomyces cerevisiae. Appl. Microbiol. Biotechnol. 42 797-806.

WEBER WJ JR (1985) Adsorption theory, concepts and models. In: Slejko FL (ed.) Adsorption Technology: A Step-by-step Approach to Process Evaluation and Application. Marcel Dekker, New York. $1-35$.

YU Q and KAEWSARN P (1999) Binary adsorption of copper (II) and cadmium (II) from aqueous solutions by biomass of marine alga Durvillaea potatorum. Sep. Sci. Technol. 34 (8) 1595-1605. 
